\title{
RRAD wt Allele
}

National Cancer Institute

\section{Source}

National Cancer Institute. RRAD wt Allele. NCI Thesaurus. Code C52601.

Human RRAD wild-type allele is located in the vicinity of $16 \mathrm{q} 22$ and is approximately $4 \mathrm{~kb}$ in length. This allele, which encodes GT P-binding protein RAD, may play a role in the mediation of the cellular response to insulin. The wild-type allele is expressed at elevated levels in patients with non-insulin resistant diabetes mellitus. 